\title{
Long-Term Summary of Ryegrass Varieties and Ploidy Types in Mississippi
}

\author{
Joshua A. White, Rocky Lemus \\ Plant and Soil Sciences, Mississippi State University, Starkville, USA \\ Email: Jwhite@pss.msstate.edu
}

Received 17 August 2014; revised 19 September 2014; accepted 6 October 2014

Copyright (C) 2014 by authors and Scientific Research Publishing Inc.

This work is licensed under the Creative Commons Attribution International License (CC BY). http://creativecommons.org/licenses/by/4.0/

(c) (i) Open Access

\section{Abstract}

Annual ryegrass (Lolium multiflourum) is the most important cool-season forage crop in Mississippi. It is seeded on more than 500,000 acres every year in the state and consequently seed companies intensely market the area with claims of superior genetic performance. Marketing literature observed in Mississippi focuses on the performance of tetraploid $(4 \times)$ versus diploid $(2 \times)$ with claims that $4 \times$ varieties provide better yield, disease resistance, and seedling vigor. These claims have rarely been substantiated on long-term performance variety trials. Archived Mississippi State forage variety test data from 1987 to 2012 were compiled for 10 diploid and tetraploid varieties grown at four physiographic locations (Starkville, Raymond, Newton, and Poplarville). Differences in the mean yields between $2 \times$ and $4 \times$ were only detected in Newton and Poplarville, where $2 \times$ varieties had a $4 \%$ yield advantage and $4 \times$ averaged $10 \%$ greater yields, respectively. Across the state, ryegrass yields for both ploidy levels increased over time $(4 \times, R=0.19931, P=$ $0.0105 \& 2 \times, R=0.18816, P=0.0003$ ), but correlations were variable by location. Biomass yields for both ploidy levels decreased over time in Starkville despite an increase in GDD (Growing Degree Days). With the exception of Raymond, year was the only factor influencing yield. The data suggest that ploidy level of ryegrass in Mississippi has minimal impact on seasonal yield production. However, genetic improvement other than polyploidy induction has increased yield over time.

\section{Keywords}

Annual Ryegrass, Diploid, Tetraploid

\section{Introduction}

Annual ryegrass (Lolium multiflorum) is the most important cool-season forage crop in Mississippi. Ryegrass is established on more than 500,000 acres every year in the state primarily for grazing cattle (especially stocker) or 
making hay or baleage. It is a $\mathrm{C}_{3}$ annual crop that is usually overseeded in the fall (September to October) into a warm-season grass sod and utilized on prepared seedbed as early as December in south Mississippi to as late as April in the northern part of the state. Varieties of ryegrass are generally divided into two ploidy types: diploids $(2 \times)$ and tetraploids $(4 \times)$. Until 1985, annual ryegrass varieties were only diploids. Tetraploids were first produced by treating germinating seeds with colchicine and selecting for plants with doubled chromosomes [1].

Tetraploids usually have wider leaves and an overall larger plant along with better disease resistance to crown rust (Puccinia coronate) [1]. These attributes have led to superior yield data reported for $4 \times$ variety releases such as Jumbo and Nelson in Louisiana and Texas [2]. Consequently this has led to the idea that tetraploids in general have higher forage yields across the Southeastern United States, resulting in the rapid adoption of recent $4 \times$ releases by producers in Mississippi. However, some multistate research has suggested that diploids may have a greater advantage in Mississippi, Georgia Alabama and even in some parts of Florida [1]. The apparent diploid advantage at these locations has been attributed to winter hardiness and to specific disease resistance [1] such as ryegrass "blast," also called gray leaf spot (Pyricularia grisea). In Mississippi, crown rust in ryegrass is not a major problem until mid-spring when ryegrass is capable of outgrowing the disease pressure or reaching maturity, thus leading into transitional summer annual forages. Alternatively, the pathogen responsible for gray leaf spot thrives in warm, humid conditions prevalent in August and September when ryegrass seedlings are emerging [3]. Though most variety testing will include several locations that include geological variability, an analysis of performance over several years has proven to be just as important in annual ryegrass trials [4].

Marshall is the most widely planted variety in Mississippi despite new commercial varieties being made available. This diploid variety released in 1981 by Mississippi State University is estimated to make up 60\% of the ryegrass acreage in the state [3]. When Marshall and Gulf, both relatively older diploid varieties, were compared to the performance of recently released varieties in Louisiana over a period of 12 years, it was found that they were relatively consistent in yield response over time and maintained good ranking within the variety test [5]. The authors later suggested that the ability of some of the recently released varieties to outperform older established varieties was due to specific environmental niches or stresses that gave a specific variety only a temporary advantage. Considering that many new varieties are developed from established varieties and or later morphed into a tetraploid, it is only rational to observe performance over several years and climatic events. It is becoming increasingly evident that climate changes may not be easily predicted and are more extreme, suggesting that a broadly adapted variety may be more advantageous to growers than varieties that are narrowly adapted. The objective of this study was to analyze ryegrass variety and ploidy performance over 25 years and to identify any correlations or trends with growing degree days and rainfall.

\section{Statistical Analysis and Data Gathering}

Yield data from the Mississippi State forage variety trials was analyzed from 1987-2012 [6]-[23]. Varieties were condensed to those that maintained a consistent presence in the variety trials after their release. From the 20 varieties chosen, half of the varieties were classified as diploid and half as tetraploid (Table 1). Growing degree days (GDD) was calculated from each location using the daily high and low temperatures archived by the Mississippi State climatologist [24]. GDD were calculated using average of the daily maximum and minimum temperatures and subtracted from a base temperature of $32^{\circ} \mathrm{F}, \mathrm{GDD}=\left(\left(\mathrm{T}_{\max }+\mathrm{T}_{\min }\right) / 2\right)-\mathrm{T}_{\text {base }\left(32^{\circ} \mathrm{F}\right)}$. The $\mathrm{T}_{\text {base }}$ temperature was based on ryegrass cold tolerance defined as stability with consecutive days under freezing temperatures [5]. Total precipitation and GDD values were calculated from September $1^{\text {st }}$ to May $1^{\text {st }}$ of each year by location.

Correlation analysis was accomplished using the PROC CORR option of SAS (SAS Institute Inc., Cary, NC) to observe significant negative or positive correlations $(P=0.05)$. Significant correlation data was then characterized using a linear regression model. Average yields were analyzed for both test to report overall performance of ploidy, location, variety, variety $\times$ location, and ploidy $\times$ location using years as reps for each variety. The statistical analysis of yield performance was done using PROC GLM option of SAS and means separated using the least significant difference (LSD) when $\alpha=0.05$ or 0.10 when otherwise noted.

The forage variety testing program has utilized several locations over the years, but only data from Starkville (Henry H. Leveck Animal Research Farm), Newton (Coast Plain Experiment Station), Poplarville (White Sands Research Unit), and Raymond (Brown Loam Branch Station) was utilized for this report. The locations were chosen simply due to the amount of variety testing data that has been recorded for ryegrass at these locations 
Table 1. Varieties of ryegrass and ploidy level including maturity and cold tolerance status.

\begin{tabular}{|c|c|c|c|c|}
\hline Ploidy & Variety & $\mathbf{N}=$ Environments (Years) & Maturity & Cold Tolerance \\
\hline \multicolumn{5}{|l|}{ Diploid } \\
\hline & Brigadier & 16 & Early & High \\
\hline & Bulldog Grazer & 20 & Early-Late & Medium-High \\
\hline & Gulf & 51 & Early-Mid & Low-Medium \\
\hline & Jackson & 59 & Mid-Late & High \\
\hline & King & 15 & Medium & Medium \\
\hline & Lonestar & 10 & Early & High \\
\hline & Marshall & 68 & Late & High \\
\hline & Passerel Plus & 33 & Late & High \\
\hline & Rio & 42 & Mid-Late & High \\
\hline & TAM90 & 48 & Mid-Late & Medium-High \\
\hline \multicolumn{5}{|c|}{ Tetraploid } \\
\hline & Big Daddy & 14 & Mid-Late & Medium \\
\hline & Diamond T & 14 & Medium & Medium-High \\
\hline & Hercules & 13 & Medium & High \\
\hline & Hurricane & 9 & $\mathrm{NA}^{\dagger}$ & NA \\
\hline & Jumbo & 29 & Late & Medium-High \\
\hline & Maximus & 14 & Medium & Medium-High \\
\hline & Multimo & 23 & NA & NA \\
\hline & Prine & 26 & Late & High \\
\hline & Tetragold & 13 & NA & NA \\
\hline & Verdue & 9 & NA & NA \\
\hline
\end{tabular}

${ }^{\dagger} \mathrm{NA}=$ Not available.

(Figure 1). The soil types are as follows: Poplarville (basin loam; coarse-loamy, siliceous, semiactive, thermic fragiapuic paleudutls), Newton (prentiss fine sandy loam; fine-loamy, sileiceous, semiactive, thermic typic fragiudults), Raymond (loring silt loam), and Starkville (marietta fine sandy loam).

For this report yields were assumed to not be affected by differing management strategies and fertilizer regiments that characterized the variety trials over the 25-year period. This variability was expected to be minimized across independent variables because of increased replications (years). Typically the number of replications or environments of which data points were derived was less with tetraploid varieties than diploid due to the relatively recent formation and adoption of tetraploid varieties.

\section{Results}

\subsection{Statistical Results}

The main effects of variety $(P=0.0018)$ and location $(P=0.0001)$ using years as replications was found to have significance. Specifically, varieties were found to interact according to location $(P=0.0008)$. When varieties were grouped by ploidy level no difference was found in means pooled across all locations. However, an interaction of location by ploidy level did exist when significance was considered at $P=0.10$. Weather ryegrass was considered, by variety or ploidy level, harvest years (replications) were different $(P=0.0001)$. Across Missis- 


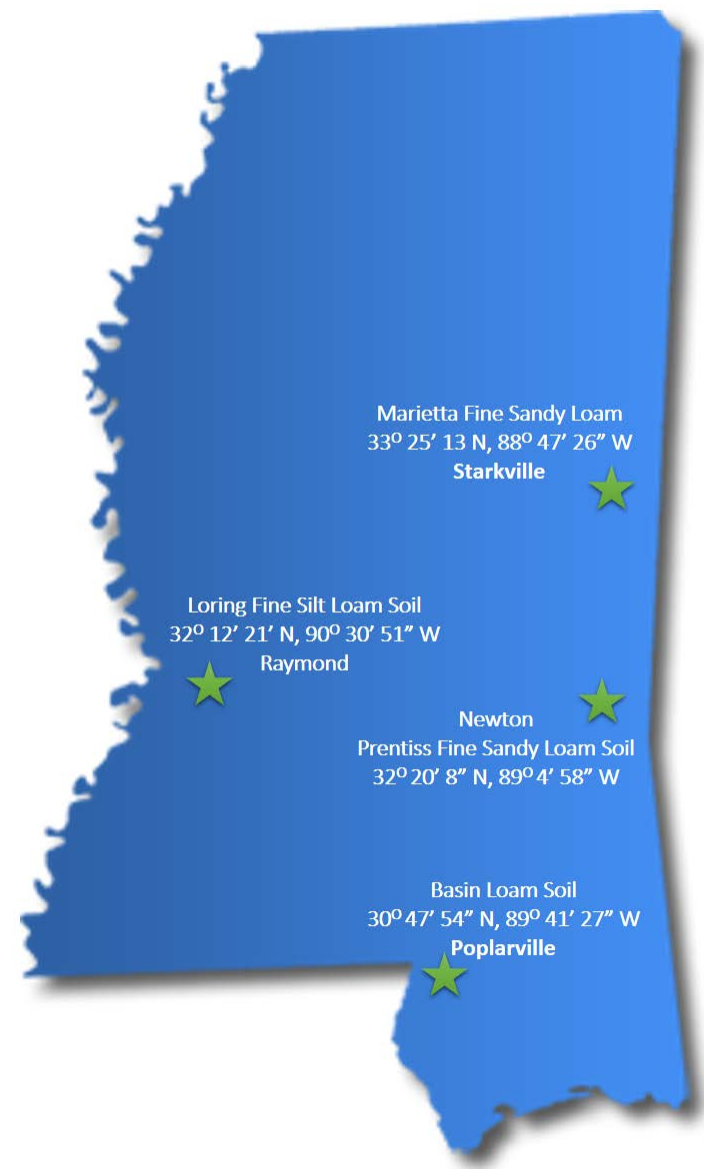

Figure 1. Locations of the annual ryegrass variety trial performance data utilized in the long-term analysis.

sippi, ryegrass yields for both types increased over time $(4 \times, R=0.19931, P=0.0105 \& 2 \times, R=0.18816, P=$ 0.0003 ), but correlations were variable by location. Growing degree days did not increase as years increased with the exception of Starkville (Table 2). Rainfall accumulation during the growing season decreased over the years in Poplarville and Newton, but increased in Raymond and remained consistent in Starkville (Table 2).

\subsection{Tetraploid and Diploid Preformance}

Differences between tetraploid and diploid ryegrass yields could not be detected at any location except Newton and Poplarville. Diploids at Newton averaged yields $4 \%$ greater than tetraploids. Alternatively, tetraploids in Poplarville had a greater advantage over diploids with a $10 \%$ increase in yield. A positive yield correlation did exist for both tetraploids $\left(R=0.19931, P^{2}=0.0105\right)$ and diploids $(R=0.18816, P=0.0003)$ as years increased. A regression model presented similar yield trends for diploids (Figure 2) and tetraploids (Figure 3). Both models retained low predictive value with a $\left(R^{2}<0.04\right)$. Correlations between yield and years were variable by location for ploidy types. Tetraploid yield at all locations with the exception of Starkville $(R=-0.37234, P=0.0180)$ had positive correlation with year. Diploid yield was only positively correlated with year at Raymond $(R=0.419$, $P=0.0001)$ and Poplarville $(R=0.509, P=0.0001)$.

In Mississippi, variety test performance data did not suggest an advantage in tetraploid over diploid biomass production. The only location could present a yield advantage from tetraploid ryegrass might be Poplarville (Southernmost location) where less cold temperatures could negatively impact growth. The results are consistent with previous research where tetraploids have shown greatest yields in Texas and Louisiana near the coast line [2]. In general, yields have increased for both ploidy types, but this trend had little association with GDD or rainfall. Considering that Starkville was the only location with decreasing yields despite increasing GDD may 


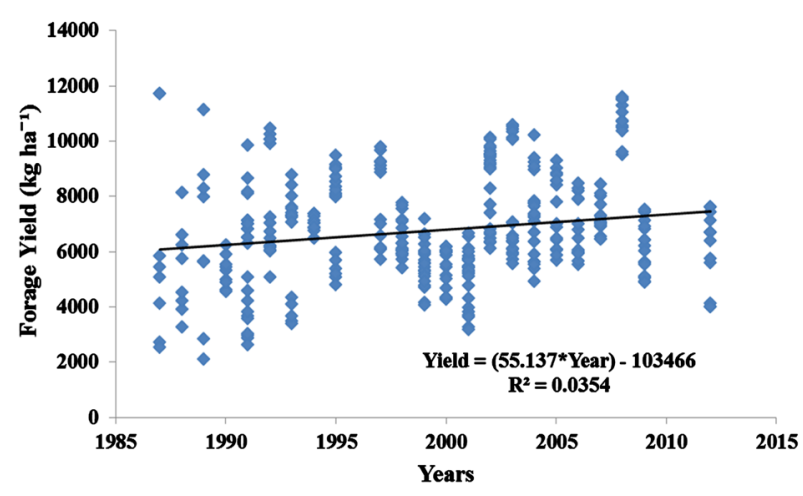

Figure 2. Yield regression over years for diploid ryegrass pooled across 4 locations in Mississippi.

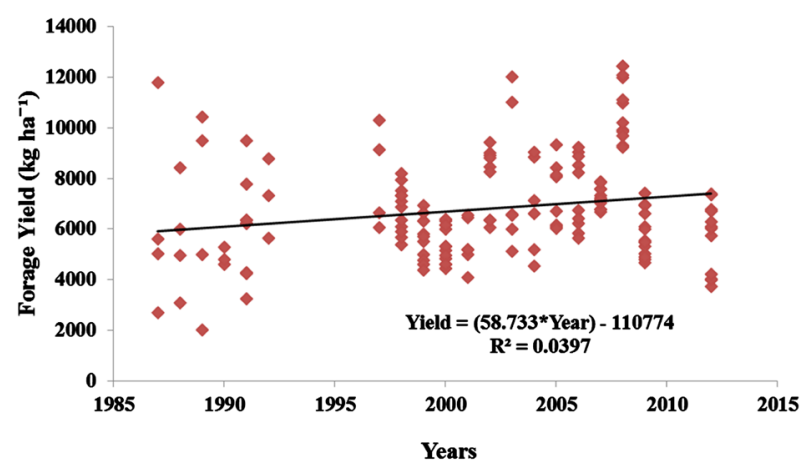

Figure 3. Yield regression over years for tetraploid ryegrass pooled across 4 locations in Mississippi.

Table 2. Years (1987-2012) correlated with growing degree days (GDD) and rainfall at Poplarville, Newton, Raymond and Starkville.

\begin{tabular}{cccccc}
\hline & & & \multicolumn{2}{c}{ Location } & \\
\hline & & Poplarville & Newton & Raymond & Starkville \\
\hline \multirow{2}{*}{ Rainfall } & $P_{\text {value }}$ & 0.0001 & 0.0110 & 0.0069 & 0.8599 \\
& $R_{\text {value }}$ & -0.5020 & -0.1803 & 0.2529 & -0.0196 \\
& $P_{\text {value }}$ & 0.0001 & 0.0479 & 0.2824 & 0.0001 \\
& $R_{\text {value }}$ & -0.4890 & 0.1407 & 0.1019 & 0.5680 \\
\hline
\end{tabular}

suggest that when temperatures are too warm in the spring we can actually expect lower total annual yields to an accelerated shutdown of plant physiological processes. This could be due to many factors including an increase in the rate of maturity by plants equivalent to less vegetative re-growth after harvest and increase in day length.

Polyploidy induction of ryegrass only promises increased advantages in very specific locations, evaluating by variety may be the most effective strategy towards proper recommendations in Mississippi.

\subsection{Variety Performance}

Varieties were greatly affected by location as presented in Table 3. Brigadier was one of the greatest producers in Raymond, but was among the lowest in Poplarville. Marshall, Jackson, and Gulf varieties commonly used in Mississippi had average yields less than the mean in Poplarville. In Newton the top producers were Diamond T and Lonestar, while Big Daddy and Lonestar had the greatest yields in Poplarville. Lonestar again produced the greatest along with Brigradier in Raymond and Starkville (the most northern location) was favored by Hercules 
Table 3. Total ryegrass yields reported from 1987-2012 and pooled across variety and location.

\begin{tabular}{|c|c|c|c|c|c|c|c|c|}
\hline \multirow[b]{2}{*}{ Variety } & \multicolumn{7}{|c|}{ Location } & \multirow[b]{2}{*}{ CV\% } \\
\hline & Ploidy & Poplarville & Newton & Raymond & Starkville & Mean & $\mathbf{L S D}_{0.05}$ & \\
\hline & \multicolumn{8}{|c|}{$\mathrm{kg} \cdot \mathrm{ha}^{-1}$} \\
\hline Big Daddy & $4 \times$ & 7681 & 6608 & 7767 & 9246 & 7826 & NS & 12.8 \\
\hline Brigadier & $2 \times$ & 4448 & 6907 & 10086 & 7980 & 7355 & 1921 & 17.8 \\
\hline Bulldog Grazer & $2 \times$ & 5567 & 7762 & 8223 & 7136 & 7172 & NS & 22.7 \\
\hline Diamond $\mathrm{T}$ & $4 \times$ & 6033 & 8110 & . & 8488 & 7544 & NS & 22.3 \\
\hline Gulf & $2 \times$ & 5461 & 7038 & 7166 & 8461 & 7032 & 1394 & 29.1 \\
\hline Hercules & $4 \times$ & 7465 & 7169 & 6035 & 11,212 & 7970 & 1629 & 13.2 \\
\hline Hurricane & $4 \times$ & 6480 & 6743 & 8551 & . & 7258 & NS & 28.4 \\
\hline Jackson & $2 \times$ & 5673 & 7817 & 8271 & 8212 & 7493 & 1180 & 24.3 \\
\hline Jumbo & $4 \times$ & 6645 & 7605 & 9178 & 7810 & 7810 & NS & 21.7 \\
\hline King & $2 \times$ & 5312 & 7148 & 7675 & 8807 & 7236 & NS & 22.5 \\
\hline Lonestar & $2 \times$ & 7525 & 8136 & 11,306 & 9456 & 9106 & NS & 27.1 \\
\hline Marshall & $2 \times$ & 5462 & 8051 & 7975 & 9073 & 7640 & 1322 & 29.1 \\
\hline Maximus & $4 \times$ & 6791 & 8121 & . & 8776 & 7896 & NS & 19.5 \\
\hline Multimo & $4 \times$ & 4739 & 7114 & 6159 & 11451 & 7366 & 2401 & 28.4 \\
\hline Passerel Plus & $2 \times$ & 6168 & 7877 & 8846 & 8794 & 7921 & 1116 & 16.1 \\
\hline Prine & $4 \times$ & 5950 & 7489 & 9950 & 8429 & 7955 & 1702 & 22.0 \\
\hline Rio & $2 \times$ & 6095 & 8067 & 8104 & 8911 & 7794 & 1073 & 18.8 \\
\hline TAM90 & $2 \times$ & 5631 & 7853 & 8200 & 8334 & 7505 & 1275 & 23.9 \\
\hline Tetragold & $4 \times$ & 6593 & 7306 & 6048 & . & 6649 & NS & 29.9 \\
\hline Verdue & $4 \times$ & 6141 & 8049 & . & 9094 & 7761 & NS & 21.1 \\
\hline Mean & & 6093 & 7549 & 8208 & 8871 & 7614 & & \\
\hline $\mathrm{LSD}_{0.05}$ & & 416 & 343 & $\mathrm{NS}^{*}$ & 558 & & & \\
\hline CV \% & & 9.4 & 7.5 & 7.4 & 7.9 & & & \\
\hline
\end{tabular}

*NS: No Significance.

and Multimo. The difference between the greatest and least producing variety by location was 3233, 1528, 5271 and $4315 \mathrm{~kg} \cdot \mathrm{ha}^{-1}$ at Poplarville, Newton, Raymond and Starkville respectively. The greatest difference between the greatest and least values was observed in Raymond which was the only location that was not significant among varieties.

Marshall annual ryegrass performance for the state of Mississippi was near average among the means in all locations while Lonestar, Prine, and Hercules were among the top producers. Although Marshall annual ryegrass remained above the mean across the state, Gulf was one of the lowest yielders among the 20 varieties. Raymond was the only location that did not have influence on varietal performance. Ryegrass in Poplarville and Newton on average produced the lowest yields across the state with Poplarville producing 32\% less forage than Starkville, where the greatest yields were recorded.

Areas along the coastal zone of the state are characterized by mild, wet winters and occasional crown rust issues, which may lend producers to consider using tetraploid varieties. However, in the central and northern regions of Mississippi, varietal stability across the state may be one method of recommendation. Varieties with the 
greatest yield across all locations would include only Lonestar, Hercules, and Maximus. Another method of varietal selection may include the function of maturity and cold tolerance. In Mississippi, varieties classifieds as mid to late maturing with at least medium cold tolerance were the greatest producers. However, very few varieties with early maturities were present in the data and no varieties with an early maturity and high cold tolerance was present, with the exception of Lonestar. Consequently, Lonestar produced the greatest forage yields in the state.

\section{Conclusions}

Ryegrass variety selection is as much a consideration of management implementation as it is about yield. This study was limited to yield results from variety testing while maturity, fiber quality, and disease pressure may have been important to evaluate as well. Considering data from this paper, recommendation of varieties may need to be adjusted especially in specific regions. Recent tetraploid marketing strategies has influenced many producers in the state, but those advantages may only be isolated to certain areas. Some older varieties may be cheaper to sow while performing similar to new more expensive releases. Similarly some varieties may be well documented to perform well, but have been rarely utilized. Varieties should be evaluated overtime over several years and locations to properly assess the adaptability of that variety to a given area.

Improvement of annual ryegrass forage yield from 1987-2012 was evident for most locations across Mississippi. This increase could be attributed to the obligatory out-crossed nature of annual ryegrass. Genetic variability or genetic drift may have shifted within the population of the variety allowing for increases in yield with no explainable environmental changes. Such conclusions may aid in future plant selection for Mississippi which may need to forgo polyploidy induction and focus other genetic improvements among top producing varieties.

\section{References}

[1] Nelson, L.R., Alison, M.W., Glass, K.M., Lang, D., Rose, P.A. and Prine, G.M. (2006) Comparison of Forage Yields of Diploid versus Tetraploid Annual Ryegrass Cultivars in the Southern USA. Proceedings of the American Forage Grassland Council, 15, 221-225.

[2] Nelson, L. and Chrowder, J. (2011) Nelson Annual Ryegrass. Journal of Plant Registrations, 5, 45-48. http://dx.doi.org/10.3198/jpr2010.02.0094crc

[3] Lemus, R. (2008) Forage Production Survey in Mississippi. Mississippi State University Extension Service. Unpublished Data.

[4] Prine, G.M. (2001) Evolutionary Recurrent Selection Develops Adapted Annual Ryegrass. Proceedings of the International Grassland Conference, Sao Paulo, 11-21 February 2001. http://www.internationalgrasslands.org/files/igc/publications/2001/id1209.pdf

[5] Redfearn, D.D., Venuto, B.C., Pitman, W.D., Blouin, D.C. and Alison, M.W. (2005) Multilocation Annual Ryegrass Cultivar Performance over a Twelve-Year Period. Crop Science, 45, 2388-2393. http://dx.doi.org/10.2135/cropsci2004.0322

[6] Edwards, N.C., Elmore, R., Hovernale, C.H., Johnson, B., Lang, D., McLean, S.D. and Watson, C.E. (1989) Winter Annual Forages 1989 Variety Trials. Mississippi State University Information Bulletin 149.

[7] Edwards, N.C., Elmore, R., Hovernale, C.H., Ingram, D.M., Ivy, R., Johnson, B., Lang, D., McLean, S.D. and Watson, C.E. (1990) Performance of Cool Season Forage Crops in Mississippi, 1989-1990. Mississippi State University Information Bulletin 175.

[8] Edwards, N.C., Elmore, R., Hovernale, C.H., Ingram, D.M., Ivy, R., Johnson, B., Lang, D. and White, R. (1991) Cool Season Forages, 1991 Variety Trials. Mississippi State University Information Bulletin 201.

[9] Edwards, N.C., Boykin, F., Elmore, R., Hovernale, C.H., Ingram, D.M., Ivy, R., Johnson, B., Pederson, D.G.A., Lang, D. and White, R. (1992) Perfomance of Forage Crop Varieties, 1991-1992 Variety Trials. Mississippi State University Information Bulletin 229.

[10] Edwards, N.C., Askew, J., Boykin, F., Burdine, W., Cuomo, G., Elmore, R., Hovernale, C.H., Ingram, D.M., Ivy, R., Johnson, B., Pederson, D.G.A., Lang, D., Saunders, R. and Tomlinson, J. (1993) Performance of Forage Crop Varieties, 1992-1993 Variety Trials. Mississippi State University Information Bulletin 247.

[11] Edwards N.C., Askew, J., Boykin, F., Burdine, W., Cuomo, G., Elmore., R., Hovernale, C.H., Ingram, D.M., Ivy, R., Johnson, B., Pederson, D.G.A., Lang, D., Saunders, R. and Tomlinson, J. (1994) Performance of Forage Crop Varieties, 1993-1994 Variety Trials. Mississippi State University Information Bulletin 269.

[12] Edwards N.C., Askew, J., Boykin, F., Burdine, W., Cuomo, G., Elmore., R., Hovernale, C.H., Ingram, D.M., Ivy, R., 
Johnson, B., Pederson, D.G.A., Lang, D., Saunders, R. and Tomlinson, J. (1995) Performance of Forage Crop Varieties, 1994-1995 Variety Trials. Mississippi State University Information Bulletin 289.

[13] Edwards N.C., Burdine, W., Elmore, R., Hovernale, C.H., Ingram, D.M., Ivy, R., Johnson, B., Pederson, D.G.A., Lang, D., Saunders, R. and Tomlinson, J. (1996) Performance of Forage Crop Varieties, 1995-1996 Variety Trials. Mississippi State University Information Bulletin 306.

[14] Edwards N.C., Burdine, W., Elmore, R., Hovernale, C.H., Ingram, D.M., Ivy, R., Johnson, B., Pederson, D.G.A. and Lang, D. (1998) Performance of Forage Crop Varieties, 1997-1998 Variety Trials. Mississippi State University Information Bulletin 342.

[15] Edwards N.C., Elmore, R., Hovernale, C.H., Ingram, D.M., Ivy, R. and Johnson, B. (1999) Performance of Forage Crop Varieties, 1998-1999 Variety Trials. Mississippi State University Information Bulletin 356.

[16] Edwards N.C., Boyd, B., Elmore, R., Hovernale, C.H., Ingram, D.M., Ivy, R. and Johnson, B. (2000) Mississippi Forage Crop Variety Trials, 2000. Mississippi State University Information Bulletin 369.

[17] Edwards, N.C., Boyd, B., Elmore, R., Hovernale, C.H., Ingram, D.M., Ivy, R., Johnson, B. and Macoon, B. (2001) Mississippi Forage Crop Variety Trials, 2001. Mississippi State University Information Bulletin 379.

[18] Lang, D., Boyd, B., Johnson, B., Macoon, B. and Smith, T. (2003) Mississippi Forage Crop Variety Trials, 2003. Mississippi State University Information Bulletin 401.

[19] Lang, D., Boyd, B., Johnson, B., Macoon, B. and Smith, T. (2004) Mississippi Forage Crop Variety Trials, 2004. Mississippi State University Information Bulletin 415.

[20] Lang, D. and Johnson, B. (2006) Mississippi Ryegrass Variety Trials, 2004-2006. Mississippi State University Information Bulletin 430 .

[21] Lang, D., Johnson, B. Shankle, B. and Parish, J.R. (2008) Mississippi Ryegrass Variety Trials, 2006-2008. Mississippi State University Information Bulletin 450.

[22] Parish, J.R. (2010) Mississippi Annual Ryegrass Variety Trials, 2008-2009. Mississippi State University Information Bulletin 455.

[23] White, J., Lemus, R., Saunders, J.R., Fitzgerald, L., Johnson, B. and Morrison, J. (2012) Mississippi Annual Cool-Season Forage Crop, 2011-2012. Mississippi State University Information Bulletin 470.

[24] Brown, M.E. (2013) State Climatologist, Mississippi State University, Personal Communication. 
Scientific Research Publishing (SCIRP) is one of the largest Open Access journal publishers. It is currently publishing more than 200 open access, online, peer-reviewed journals covering a wide range of academic disciplines. SCIRP serves the worldwide academic communities and contributes to the progress and application of science with its publication.

Other selected journals from SCIRP are listed as below. Submit your manuscript to us via either submit@scirp.org or Online Submission Portal.
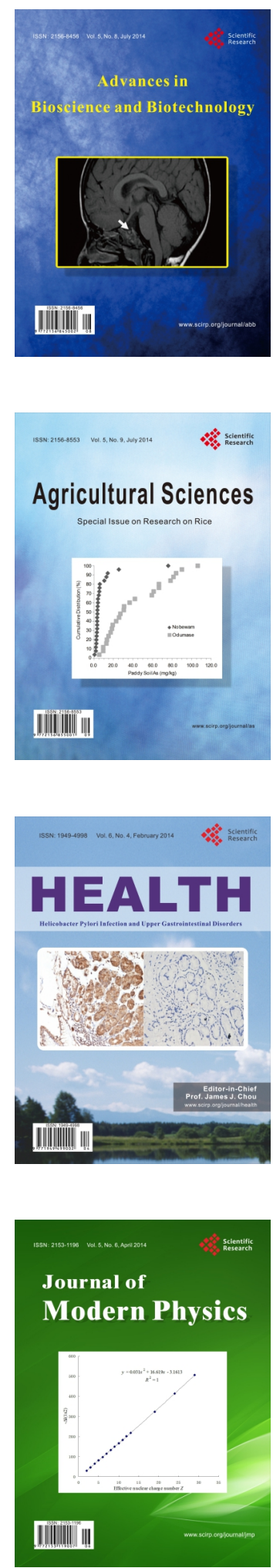
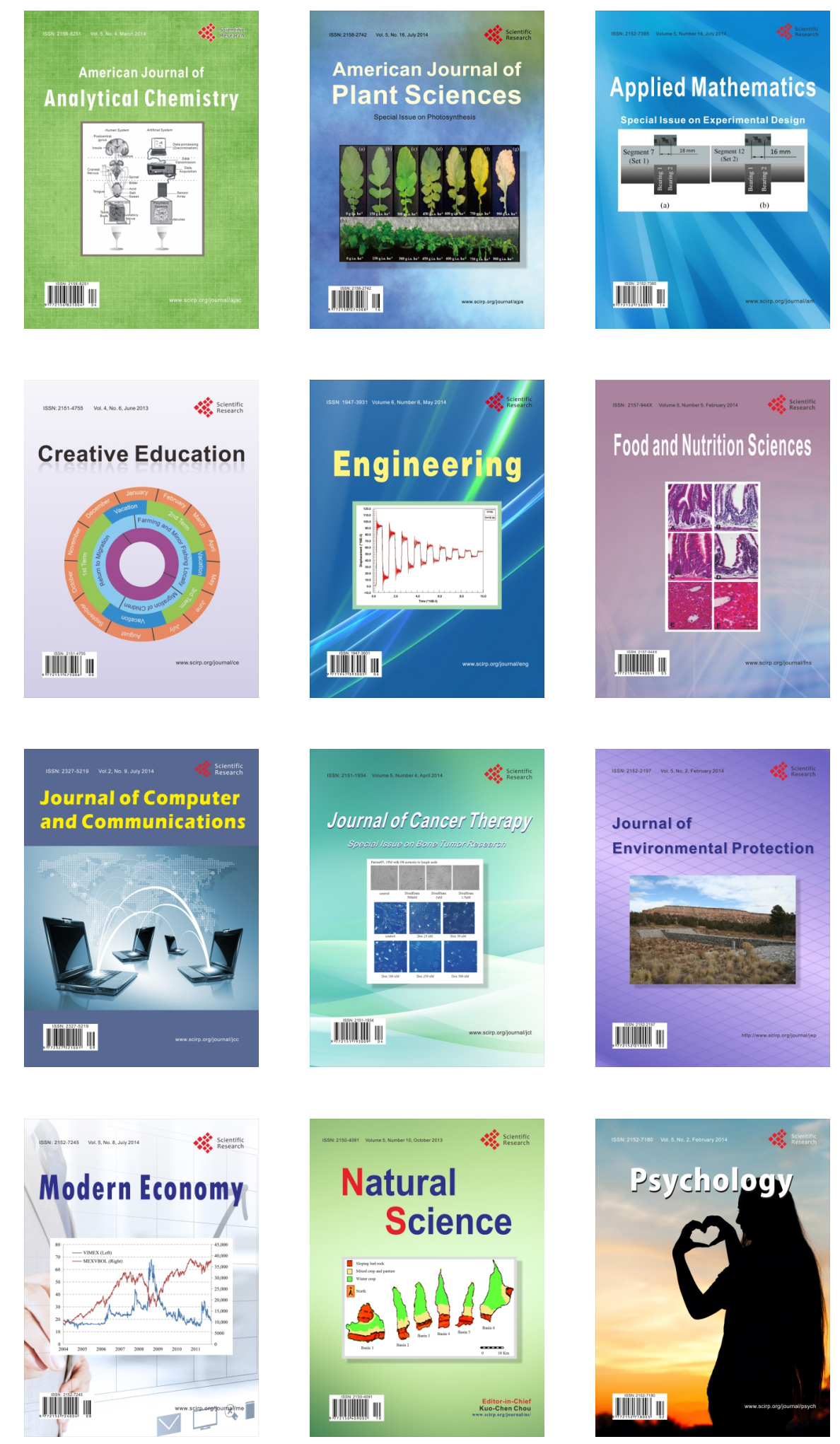